OPEN ACCESS

Edited by:

Margot Schulz,

Universität Bonn, Germany

Reviewed by:

Benjamin Fuchs,

Freie Universität Berlin, Germany

Chunjie Li,

Lanzhou University, China

*Correspondence:

Pedro E. Gundel

gunde/@agro.uba.ar

Specialty section:

This article was submitted to

Chemical Ecology,

a section of the journal

Frontiers in Ecology and Evolution

Received: 08 October 2018 Accepted: 27 November 2018

Published: 11 December 2018

Citation:

Gundel PE, Seal CE, Biganzoli F, Molina-Montenegro MA,

Vázquez-de-Aldana $B R$

Zabalgogeazcoa I, Bush LP, Martínez-Ghersa MA and Ghersa CM

(2018) Occurrence of Alkaloids in

Grass Seeds Symbiotic With Vertically-Transmitted Epichloë Fungal Endophytes and Its Relationship With Antioxidants. Front. Ecol. Evol. 6:211. doi: 10.3389/fevo.2018.00211

\section{Occurrence of Alkaloids in Grass Seeds Symbiotic With Vertically-Transmitted Epichloë Fungal Endophytes and Its Relationship With Antioxidants}

\author{
Pedro E. Gundel ${ }^{1 *}$, Charlotte E. Seal ${ }^{2}$, Fernando Biganzoli ${ }^{3}$, \\ Marco A. Molina-Montenegro ${ }^{4,5}$, Beatriz R. Vázquez-de-Aldana ${ }^{6}$, Iñigo Zabalgogeazcoa ${ }^{6}$, \\ Lowell P. Bush ${ }^{7}$, María A. Martínez-Ghersa ${ }^{1}$ and Claudio M. Ghersa ${ }^{1}$ \\ ${ }^{1}$ IFEVA, Facultad de Agronomía, Universidad de Buenos Aires, CONICET, Buenos Aires, Argentina, ${ }^{2}$ Department of \\ Comparative Plant and Fungal Biology, Royal Botanic Gardens, Kew, United Kingdom, ${ }^{3}$ Departamento de Métodos \\ Cuantitativos y Sistemas de Información, Facultad de Agronomía, Universidad de Buenos Aires, Buenos Aires, Argentina, \\ ${ }^{4}$ CEMF, Instituto de Ciencias Biológicas, Universidad de Talca, Talca, Chile, ${ }^{5}$ CEAZA, Universidad Católica del Norte, \\ Coquimbo, Chile, ${ }^{6}$ Instituto de Recursos Naturales y Agrobiología de Salamanca (IRNASA-CSIC), Salamanca, Spain, \\ ${ }^{7}$ Department of Plant \& Soil Sciences, University of Kentucky, Lexington, KY, United States
}

Host organisms can acquire new functional traits through symbiosis. Seed-transmitted Epichloë fungal endophytes are known to protect host plants against herbivores and increase tolerance to abiotic stresses by alkaloids and antioxidants, respectively (currencies of mutualism). Whereas, alkaloids are fungal products with demonstrated effects at plant vegetative stage, few studies have focused on alkaloids in seeds. We assessed the occurrence of fungal alkaloids and determined their concentrations in seeds of two host grasses, Festuca rubra and Lolium multiflorum. Then, we sought for a relationship with the antioxidants tocochromanols and glutathione, which are involved in the control of oxidative stress. Different alkaloids were detected depending on the species and plant genotype. Most notably, loline alkaloids were not detected in F. rubra seeds, whereas ergovaline and peramine were absent in L. multiflorum. In F. rubra, ergovaline concentration was dependent on the maternal line in interaction with the production year, diminishing in seeds after 1 year of storage. The exposure of $L$. multiflorum plants to ozone had no effect on the seed concentration of lolines. There was a significant positive relationship between the concentrations of ergovaline and tocochromanols in both species, and between ergovaline concentration and E $_{\mathrm{GSSG} / 2 \mathrm{GSH}}$ (glutathione halfcell reduction potential) in RAB maternal line of $F$. rubra. These results suggest that alkaloid and antioxidants have a close association in seeds of host grasses, and that the alkaloid bioactivity could be related with the antioxidant capacity to control stress. This has important implications for the ecology of partner species, thus supporting its consideration for further research.

Keywords: grass-endophyte symbiosis, secondary compounds, defensive mutualism, currency of mutualism, seed quality 


\section{INTRODUCTION}

Host organisms can acquire new functional traits through symbiosis (Kiers and West, 2015). In the symbiosis between cool-season grasses (Subfamily Poöideae) and Epichloë fungal endophytes (Clavicipitaceae) (reviewed by Clay and Schardl, 2002), the high prevalence of symbiotic individuals in populations has been ascribed to both an endophyte-mediated resistance to herbivory by alkaloids and tolerance to abiotic stress by antioxidants, known as the "currencies of the mutualism" (Schardl et al., 2007; Hamilton and Bauerle, 2012). Nonetheless, the effects of fungal endophytes on host plant fitness can vary depending to partners' species and genotypes, and as a result of the ecological context (Clay and Schardl, 2002; Saikkonen et al., 2013).

Seeds are critical to the grass-endophyte symbiosis as fungus carriers from one generation to the next (Gundel et al., 2011a, 2017). The seed is the plant structure with the greatest fungus/plant biomass ratio which stores fungal alkaloids (TePaske et al., 1993; Justus et al., 1997; Vázquez-de-Aldana et al., 2003). The profile and concentration of alkaloids varies greatly responding to factors such as species identities, plant tissue/stage, and growth conditions (Bush et al., 1997; Faeth et al., 2002; Rasmussen et al., 2007; Mace et al., 2014). Production of alkaloids can be triggered by herbivory (Sullivan et al., 2007; Fuchs et al., 2017a), although it remains unknown whether alkaloids accumulate in seeds as a consequence (Gundel et al., 2017). Endophyte presence in seeds is deemed to deter granivorous animals (Uchitel et al., 2011), an effect that may be extended to protect seedlings from herbivores (Stewart, 1985; Czarnoleski et al., 2010). However, the endophyte-conferred resistance in seedlings may be ineffective (Lewis and Clements, 1986) because of a very low alkaloid level (Dymock et al., 1989) and/or because of fungus viability loss. Since the alkaloids are present in the seed, their loss rate could be independent of the endophyte viability (Stewart, 1985), but dependent on seed quality parameters.

A potentiated antioxidant system is proposed as a mechanism by which symbiotic plants usually exhibit higher tolerance to abiotic stress (White and Torres, 2010; Hamilton et al., 2012). The presence of endophytes in seeds may be related to a higher antioxidant capacity. For example, endophytic seeds of F. rubra (RAB maternal line) had a higher concentration of the lipidsoluble antioxidants $\alpha$-tocopherol and $\alpha$-tocotrienol than nonendophytic seeds (Gundel et al., 2012), that may contribute to stabilize membrane functionality (Falk and Munné-Bosch, 2010). In contrast, the glutathione half-cell reduction potential $\left(\mathrm{E}_{\mathrm{GSSG} / 2 \mathrm{GSH}}\right.$ ), a marker of the cellular redox state that shifts toward positive values with a loss of seed viability (Kranner et al., 2010; Seal et al., 2010), was more positive in endophytic compared to non-endophytic seeds of L. multiflorum (Gundel et al., 2015). However, the presence of an endophyte does not always contribute toward viability. Whereas endophytes enhance the survival of germinating seeds in L. multiflorum and F. rubra (Gundel et al., 2006, 2011b), they had a negative effect on seed viability under both cool-dry and wet-warm storage conditions (Gundel et al., 2012, 2015). Therefore, endophyte effects on seeds may differ depending on the plant species, seed quality, seed storage conditions and antioxidant.

With growing evidence beginning to elucidate the ecological functions of alkaloids and antioxidants in the grass-endophyte symbiosis independently, it is striking that any relationship between these two compounds is yet to be explored. Here, we first present data on the concentration of different fungal alkaloids in seeds of two grass species, F. rubra and L. multiflorum. With the aim to have within-species variation in the profile and level of alkaloids, we analyzed seeds produced by different plants and years in the case of F. rubra, and produced in atmospheres with high and low concentration of ozone in the case of $L$. multiflorum. Ozone is a stress factor associated to tropospheric contamination that depending on the intensity, can cause growth loses or induced resistance in plants by activating the antioxidant system (Menéndez et al., 2009). Then, we explored the existence of relationships between alkaloids and antioxidants. A relationship between these currencies of mutualism could have significant ecological consequences: a negative relationship elicited by different factors (i.e., antioxidants to abiotic stress and alkaloids to herbivory) would mean that the occurrence of a given factor (e.g., stress factor) would render the plant susceptible to another factor (e.g., herbivory) and vice-versa. Alternatively, a positive relationship would indicate that a lower concentration of antioxidants would imply a lower concentration of alkaloids and consequently seeds may be more prone to herbivory.

\section{MATERIALS AND METHODS}

\section{Seed Material}

\section{Festuca rubra}

We used half-sib seeds produced by clones of three individual plants (RAB, SAN, and PEN) infected by Epichloë festucae, the common fungal endophyte of fine fescues (Zabalgogeazcoa et al., 2006; Dirihan et al., 2016). The original plants were collected from three sites separated by at least $40 \mathrm{~km}$, in dehesa grasslands of Salamanca, Spain. Epichloë fungal endophytes have shown to affect different growth attributes and biochemical variables of those maternal lines (Zabalgogeazcoa et al., 2006; Vázquez-de-Aldana et al., 2013). Each plant was split into three ramets, randomly transplanted in a field plot on a research farm (IRNASA-CSIC, Salamanca, Spain; Gundel et al., 2011b). The seeds were produced in 3 years: 2009, 2010, and 2011, and stored for 24,12 , and 1 month, respectively, under dry and cold $\left(10^{\circ} \mathrm{C}\right)$ conditions. In 2012 , seed lots produced by each maternal line and ramet $(n=2$; since a ramet was lost in two of the maternal lines, we decided to used just 2 ramets each) in each year, were processed for alkaloid determination.

\section{Lolium multiflorum}

The original population was collected in a semi-natural grassland (Pampa Region, Argentina) where populations usually present high frequency of endophyte-infected plants (Gundel et al., 2009). In 2011, L. multiflorum plants with and without Epichloë occultans were exposed to a high concentration of tropospheric ozone (Gundel et al., 2015). At pre-anthesis, 64 plants growing 
independently in $2 \mathrm{~L}$ pots were placed in any of the 8 open-top chambers with either high $(\approx 120 \mathrm{ppb})$ or low $(<10 \mathrm{ppb})$ levels of ozone for 5 days ( $2 \mathrm{~h}$ at noon). Seeds produced by all the plants within an open-top chamber were pooled and stored in dry and cold conditions for 3 months. In 2012, seed lots produced by all the plants within a chamber were pooled $(n=4$ for each ozone treatment) and were processed for alkaloid determination.

\section{Alkaloid Analysis}

Concentration of the ergopetine alkaloid, ergovaline (Chemical name: 12'-Hydroxy-2'-methyl-5' alpha(1-methylethyl)-ergotaman- $3^{\prime}, 6^{\prime}, 18$-trione) was quantified by HPLC following a modification of the methods described by Hill et al. (1993) and Yue et al. (2000). A $1.0 \mathrm{~g}$ ground seed sample was extracted in $20 \mathrm{ml}$ of $\mathrm{CHCl}_{3}$ and $1 \mathrm{ml}$ of $0.5 \mathrm{mM} \mathrm{NaOH}$ for $2 \mathrm{~h}$. A solution $\left(10 \mu \mathrm{g} \mathrm{mL}^{-1}\right)$ of ergotamine ditartrate (Sigma-Aldrich) was added as internal standard. The mixture was vacuum-filtered through Whatman $\mathrm{n}^{\circ} 2$ filter paper and a $10 \mathrm{ml}$ aliquot of filtrate was passed through a $500 \mathrm{mg}$ Ergosil (Analtech; Newark, USA) solid-phase column preconditioned with $\mathrm{CHCl}_{3}$. Plant pigments were removed with $5 \mathrm{ml}$ of chloroform:acetone (1:3). The sample was eluted with $2 \mathrm{ml}$ of methanol and vacuum concentrated, redissolved in $1 \mathrm{ml}$ of methanol, and filtered through a $0.22 \mu \mathrm{m}$ nylon filter. Ergovaline quantification in extracts was performed in a HPLC system (Waters 2690) with an Xterra MS C18 Waters column $(4.6 \times 100 \mathrm{~mm})$ and a fluorescence detector (Waters 2475) $\lambda_{\operatorname{exc}}$ $=250 \mathrm{~nm}$ and $\lambda_{\mathrm{em}}=420 \mathrm{~nm}$. The mobile phase was acetonitrile and $0.01 \mathrm{M}$ ammonium acetate with a gradient flow of $0.8 \mathrm{ml}$ $\min ^{-1}$.

Peramine (Chemical name: 2-[3-(2-methyl-1-oxopyrrolo[1,2a]pyrazin-3-yl)propyl]guanidine) was determined using the HPLC method described by Barker et al. (1993) and Yue et al. (2000). A freeze-dried and ground sample (100 mg) was extracted in $3 \mathrm{ml}$ of $30 \%$ isopropanol for $30 \mathrm{~min}$ at $90^{\circ} \mathrm{C}$. The mixture was centrifuged and the extract was passed through a preconditioned Varian Bond Elut carboxylic acid (CBA) column packed with $100 \mathrm{mg}$ of adsorbent. After a wash of the column with $1-2 \mathrm{ml}$ of methanol, peramine was eluted with $1 \mathrm{ml}$ of $5 \%$ formic acid in $80 \%$ aqueous methanol. The extract was filtered through a $0.22 \mu \mathrm{m}$ nylon filter and chromatographed in a Waters 2690 system with a Nova Pak C18 Waters column $(3.9 \times 150 \mathrm{~mm})$. The isocratic mobile phase consisted of $18 \%(\mathrm{v} / \mathrm{v})$ acetonitrile in a guanidine carbonate (10 mM)-formic acid buffer. Detection was performed with a Photodiode Array Detector (Waters 2996) at $280 \mathrm{~nm}$. For more details see Vázquez-de-Aldana et al. (2010).

Pyrrolizidine alkaloids (NANL: N-acetilnorloline, NFL: $\mathrm{N}$-formylloline, and NAL: N-acetylloline) [Chemical name: (6r,7r,7as)-n-methylhexahydro-1h-1,6-epoxypyrrolizin-7-

amine] were extracted from powdered plant material with ethanol:methylene chloride $(4: 1, \mathrm{v} / \mathrm{v})$ containing internal standard quinoline and sodium bicarbonate following protocol in Helander et al. (2016). Individual alkaloids were resolved and quantified by GC equipped with FID detector. Chromatographic conditions were $15 \mathrm{~m} \times 0.53 \mathrm{~mm} \mathrm{DB} 5$ column with initial oven temperature of $70^{\circ} \mathrm{C}$ increased to $160^{\circ} \mathrm{C}$ at $45^{\circ} \mathrm{C} \mathrm{min}{ }^{-1}$, held for $5 \mathrm{~min}$ and increased to 290 at $45 \mathrm{~min}^{-1}$ and held for $7 \mathrm{~min}$.

\section{Antioxidant Analysis}

In searching for relationships with the alkaloids, we focussed on total tocochromanols (that comprises several independent compounds of tocopherols and tocotrienols) and the glutathione half-cell reduction potential $\left(\mathrm{E}_{\mathrm{GSSG} / 2 \mathrm{GSH}}\right)$ that were found to be higher in concentration (tocochromanols) or more negative $\left(\mathrm{E}_{\mathrm{GSSG} / 2 \mathrm{GSH}}\right.$ ) in the presence of seed endophytes (Gundel et al., 2012, 2015). Published values were taken from our earlier works which analyzed the same seed lots (Gundel et al., 2012, 2015).

\section{Data Analysis}

We built generalized least squares models (gls function, nlme package, Pinheiro et al., 2017) in R (R. Core Team, 2017) to test the effects of the different variation factors on the concentration of alkaloids in seeds. In the case of F. rubra, the alkaloid was ergovaline while the factors were maternal line (PEN and RAB; SAN was not included in the analysis since we did not detect ergovaline) and production year (2009, 2010, and 2011). In the case of L. multiflorum, the alkaloids were "total lolines" and derivatives (NANL, NFL, and NAL) as affected by the maternal exposure to ozone. When necessary, we also modeled variance heterogeneity of errors with the option weights. Significance was tested with Type II Likelihood Ratio Test (car package; Fox and Weisberg, 2011). Finally, we tested the relationship between the alkaloids (ergovaline and total lolines) with the total tocochromanols and the $\mathrm{E}_{\mathrm{GSSG} / 2 \mathrm{GSH}}$ in the seeds.

\section{RESULTS}

\section{Festuca rubra}

Loline alkaloids were not detected in any of the assessed F. rubra seed. The alkaloid peramine was only present in seeds of the maternal line PEN produced in $2010\left(3.12 \pm 0.01 \mu \mathrm{g}^{-g^{-1}}\right)$ and 2011 (5.68 $\pm 0.01 \mu \mathrm{g} . \mathrm{g}^{-1}$; Table 1).

Ergovaline was not detected in seeds from the maternal line SAN in any of the production years (Table 1). The concentration of ergovaline in seeds of the other two maternal lines was found dependent on production year $\left(X_{1}^{2}=302.870, P<0.001\right)$. The concentration in seeds of RAB was 15 -fold higher in comparison to that of PEN with a mean difference across production years of $0.61 \mu \mathrm{g} \cdot \mathrm{g}^{-1}$ (Table 1).

Ergovaline concentration was related to tocochromanol concentrations but varied between maternal lines $\left(X_{1}^{2}=20.492, P\right.$ $<0.001)$. For the RAB lineage, a significant positive relationship between the alkaloid and tocochromanol concentrations was apparent, although this relationship was not related with the production year $\left(X_{1}^{2}=0.003, P=0.956\right.$; Figure 1A). The relationship between alkaloid and tocochromanol concentration was not significant in PEN.

Independently of the year $\left(X_{1}^{2}=2.065, P=0.151\right)$ but influenced by the maternal line $\left(X_{1}^{2}=37.944, P<0.001\right)$, the concentration of ergovaline was negatively related to $\mathrm{E}_{\mathrm{GSSG} / 2 \mathrm{GSH}}$ for RAB but positively related for PEN (Figure 1B).

\section{Lolium multiflorum}

Neither ergovaline nor peramine were detected in any of the $L$. multiflorum seed lots (Table 1). 
TABLE 1 | Concentration of fungal alkaloids in endophyte-symbiotic seeds of Festuca rubra and Lolium multiflorum as affected by "maternal line and production year", and "maternal exposure to ozone," respectively.

\begin{tabular}{|c|c|c|c|c|c|}
\hline \multirow[t]{2}{*}{ Species } & \multicolumn{2}{|c|}{ Variation factor } & \multicolumn{3}{|c|}{ Alkaloid } \\
\hline & Maternal line & Production year & $\begin{array}{c}\text { Ergovaline } \\
\left(\mu \mathbf{g . g}^{-1} \mathrm{DM}\right)\end{array}$ & $\begin{array}{c}\text { Lolines } \\
\left(\mu \mathbf{g}^{-g^{-1}} \mathrm{DM}\right)\end{array}$ & $\begin{array}{c}\text { Peramine } \\
\left(\mu \mathbf{g} \cdot \mathrm{g}^{-1} \mathrm{DM}\right)\end{array}$ \\
\hline \multirow[t]{10}{*}{ Festuca rubra } & SAN & 2009 & n.d. & n.d. & n.d. \\
\hline & & 2010 & n.d. & n.d. & n.d. \\
\hline & & 2011 & n.d. & n.d. & n.d. \\
\hline & PEN & 2009 & $0.08(0.00)$ & n.d. & n.d. \\
\hline & & 2010 & $0.01(0.00)$ & n.d. & $3.12(0.01)$ \\
\hline & & 2011 & $0.04(0.00)$ & n.d. & $5.68(0.01)$ \\
\hline & $\mathrm{RAB}$ & 2009 & $0.43(0.01)$ & n.d. & n.d. \\
\hline & & 2010 & $0.80(0.02)$ & n.d. & n.d. \\
\hline & & 2011 & $0.72(0.02)$ & n.d. & n.d. \\
\hline & Maternal ozone & & & & \\
\hline \multirow[t]{2}{*}{ Lolium multiflorum } & high ( $\approx 120$ ppb) & & n.d. & $1440.75(226.00)$ & n.d. \\
\hline & low (< 10 ppb) & & n.d. & $1426.50(171.74)$ & n.d. \\
\hline
\end{tabular}

Values are mean (SE); $n=2$, and $n=4$, for $F$. rubra and L. multiflorum, respectively.

The exposure of mother plants to ozone did not affect either the concentration of total lolines in the seed $\left(X_{1}^{2}=0.003, P=\right.$ 0.961 ; Table 1) nor that of the lolines individually (NANL: $X_{1}^{2}=$ $0.820, P=0.365$, NFL: $X_{1}^{2}=0.046, P=0.831$, and NAL: $X_{1}^{2}=$ $0.001, P=0.974)$. The average concentration of each individual loline alkaloid in seeds produced by mother plants treated and non-treated with ozone was $254.87 \pm 20.84,1147.12 \pm 113.43$, and $31.625 \pm 3.49$ (mean \pm SE; $\mu \mathrm{g} \cdot \mathrm{g}^{-1} \mathrm{DM}$ ) for NANL, NFL, and NAL, respectively.

A significant positive relationship between the concentration of lolines and tocochromanols $\left(X_{1}^{2}=11.693, P=0.001\right)$ was independent of mother plants exposure to ozone $\left(X_{1}^{2}=2.773\right.$, $P=0.096$; Figure 1C). There was no relationship between loline concentration and $\mathrm{E}_{\mathrm{GSSG} / 2 \mathrm{GSH}}\left(X_{1}^{2}=0.133, P=0.715\right.$; Figure 1D).

\section{DISCUSSION}

Here we showed that, despite variability accounted for by genotype and species identity and the environmental conditions of seed production, seeds are carriers of fungal alkaloids, and the concentration may be related with the antioxidants system of the seeds. Because antioxidants are related to seed quality and functionality (Kranner et al., 2010; Seal et al., 2010), they may also be involved in the control of endophyte longevity (Gundel et al., 2012, 2015) and alkaloids bioactivity. Although more studies are certainly required, the two currencies of mutualism (Schardl et al., 2007; Hamilton and Bauerle, 2012) appear as fundamental but interactive players for the ecological fate of the symbiotic unit (i.e., the seed). By joining host grass life cycle, fungal endophytes multiply and disperse through the seed (Gundel et al., 2011a). Thus, seeds are a crucial structure to protect (Gundel et al., 2017).

The alkaloid ergovaline is mainly known due to its toxicity on mammals (Bush et al., 1997; Saikkonen et al., 2013), although it can also be effective in deterring herbivorous insects (Potter et al., 2008). The concentration of the alkaloid ergovaline varies greatly among plant species, genotypes and tissues (Schardl et al., 2013; Mace et al., 2014). A great variation was previously shown between plants $\left(0-0.47 \mu \mathrm{g}^{-g^{-1}}\right)$ in stems and leaves of F. rubra (Vázquez-de-Aldana et al., 2007, 2010). In our study, the concentrations of ergovaline in seeds were similar to those found in plant vegetative tissues in Italian ecotypes (Jensen et al., 2007) but lower than those from Switzerland (Leuchtmann et al., 2000). An ergovaline concentration of $0.40 \mu \mathrm{g}^{-g^{-1}}$ is considered a critical threshold in cattle diets above which symptoms of toxicosis can be observed (Bony and Delatour, 2001). Although much lower than the concentration found in

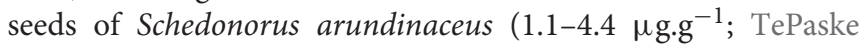
et al., 1993), the seeds produced by the RAB plants exhibited seed alkaloid concentrations higher than the toxicosis threshold (from 0.41 to $0.83 \mu \mathrm{g} . \mathrm{g}^{-1}$ ), being probably effective in deterring small rodents and herbivorous insects. Additionally, the observed variation among plants in alkaloid profile and concentration would indicate potential for populations to respond to selection pressures exerted by herbivory.

A similar variation has been observed in plant species associated with loline-producing endophytes. Concentration of lolines in L. multiflorum seeds showed high variability $(880-1,922$ $\left.\mu \mathrm{g} . \mathrm{g}^{-1}\right)$ but it was on average significantly higher $(\approx 1430.63$ $\left.\mu \mathrm{g} . \mathrm{g}^{-1}\right)$ compared to the concentration found in dry seed of the same species previously (TePaske et al., 1993) $\left(\approx 52 \mu \mathrm{g}^{-\mathrm{g}^{-1}}\right)$. However, the concentrations of lolines we found are slightly lower to that reported for $F$. pratensis dry seeds $\left(\approx 1,801 \mu \mathrm{g} . \mathrm{g}^{-1}\right)$ by Justus et al. (1997). The fungal endophytes of these two last grass species, E. occultans and E. uncinatum, are wellknown as loline-producing endophytes and the latter one is known for its high production level (Schardl et al., 2007). Since lolines are insect deterrents and non-toxic for vertebrates, forage species infected with those endophytes such as L. multiflorum, $L$. rigidum, and $F$. pratensis, are naturally protected against 

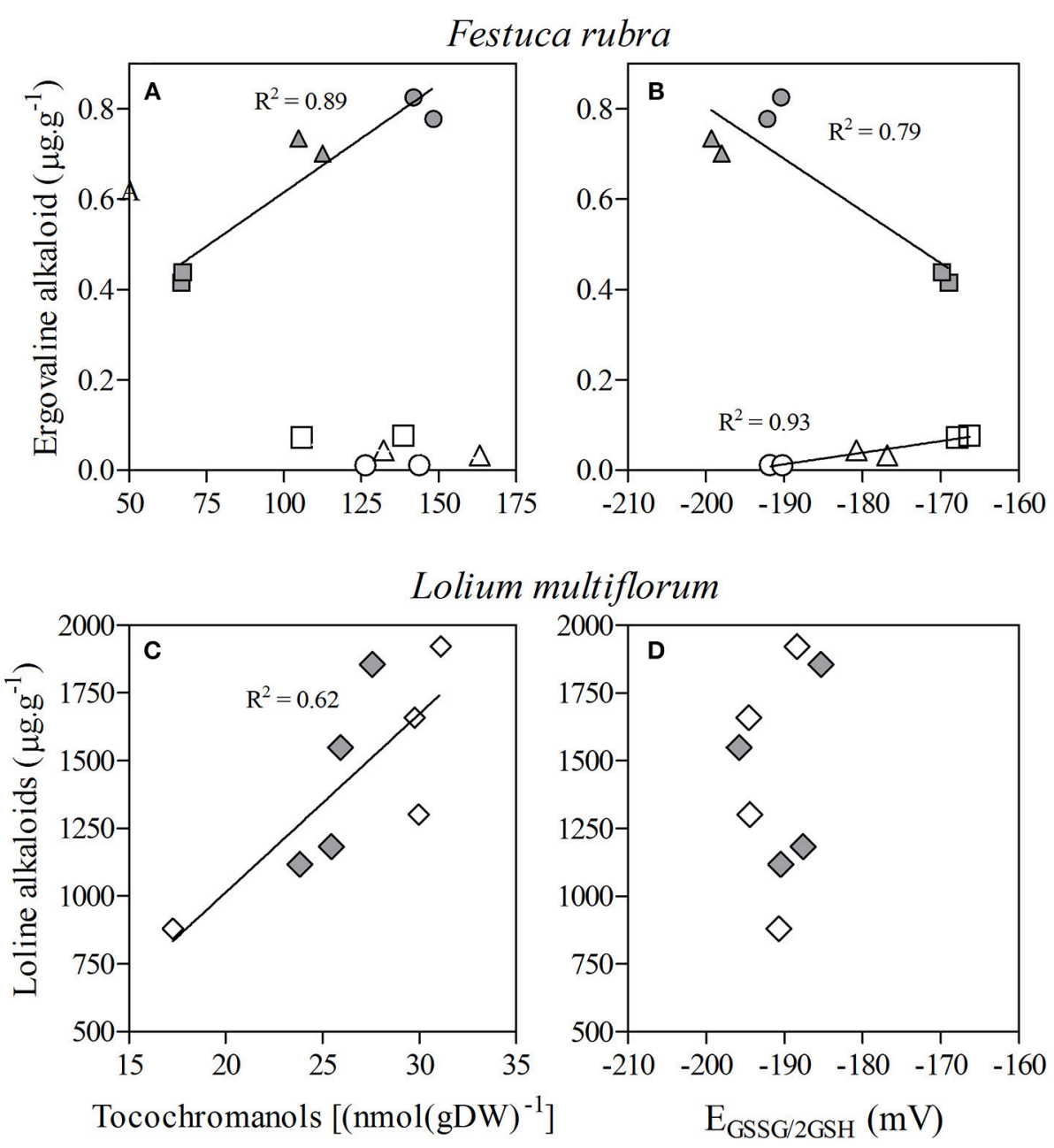

FIGURE 1 | (Upper) Relationship between the concentration of the alkaloid ergovaline and antioxidant (total) tocochromanols (A) and the glutathione half-cell reduction potential (EGSG/2GSH) (B) in seeds of two maternal lines (PEN and RAB, white and gray symbols, respectively) of Festuca rubra symbiotic with the fungal endophyte Epichloë festucae, produced in three different years: 2009 (squares), 2010 (circles), and 2011 (triangles). Regression lines and coefficient of determinations are only shown when significant $(P<0.05)$ and are calculated for a given data set (e.g., RAB). (Lower) Relationship between the concentration of loline alkaloids and antioxidant (total) tocochromanols (C) and the glutathione half-cell reduction potential ( $\mathrm{E}_{\mathrm{GSSG} / 2 \mathrm{GSH}}$ ( (D) in seeds produced by Lolium multiflorum plants symbiotic with the fungal endophyte Epichloë occultans exposed to high ( $\approx 120$ ppb, gray diamonds) or low (<10 ppb, white diamonds) ground-level ozone. Since there was no effect of ozone, the regression line and coefficient of determination correspond to the whole data set and is significant at $P<0.05$.

agricultural plagues. Lolines are also found in seeds of $S$. arundinaceus infected by E. coenophiala (Jackson et al., 1984). The existence of strains producing lolines and/or peramine but not ergovaline or lolitrem-B (that are toxic for livestock) is the foundation of the use of the "safe-endophyte technology" in forage breeding (Gundel et al., 2013). This technology relies on the quality of the seeds since not only the fungus but also its alkaloids determine its successful application in agriculture.

Interestingly, even though the gene required for the peramine (perA) is found in E. occultans, the alkaloid remains undetected in tissue and now in seeds, of Lolium multiflorum (Bastías et al., 2017). Peramine is a unique and potent insecticide fungal alkaloid (Bush et al., 1997; Schardl et al., 2013). Here, it was only detected in seeds produced by the F. rubra PEN but with variation among years. There was a clear relationship between the level of peramine and the year (2009: $0 \mu \mathrm{g} . \mathrm{g}^{-1}, 2010: 3.12 \mu \mathrm{g} . \mathrm{g}^{-1}$, and 2011: $5.68 \mu \mathrm{g} . \mathrm{g}^{-1}$, corresponding to 24,12 , and 1 month of storage) suggesting a susceptibility to denaturalize with time. It was found in L. perenne that the level of peramine follows the growing cycle of the host grass, showing a minimum $(<1.0$ $\left.\mu \mathrm{g} . \mathrm{g}^{-1}\right)$ in winter and a maximum $\left(4-8 \mu \mathrm{g} . \mathrm{g}^{-1}\right)$ in summer (Fuchs et al., 2017b). With a suggested threshold of $2 \mu \mathrm{g} \cdot \mathrm{g}^{-1}$ for peramine to be effective against herbivores (see references in Fuchs et al., 2017b), the concentration observed in seeds of PEN F. rubra line has the potential to be preserved for up to 1 year of storage.

Unlike the alkaloids, for which the genetic information for their synthesis is encoded in the endophyte genome 
(Schardl et al., 2013), both the plant and the fungus can, in principle, produce molecules with antioxidant capacity (Huang et al., 2007). However, no precise information exists regarding the direct contribution of the fungus toward the antioxidant activity of plants (Hamilton et al., 2012) and their seeds (Gundel et al., 2012, 2015). Our results support the hypothesis that there is a positive relationship between both these two groups of secondary compounds. It was particularly evident for ergovaline in F. rubra RAB maternal line, as the concentration of alkaloid was related to a higher antioxidant capacity with regard to both tocochromanols and $\mathrm{E}_{\mathrm{GSSG} / 2 \mathrm{GSH}}$, whereas in L. multiflorum seeds, a positive relationship was only found between loline alkaloids and tocochromanols.

The functionality of both tocochromanols and glutathione in the seed has implications for the ecology of the species. Previous studies that show a protective role of endophytes on seeds and seedlings, highlight alkaloids as the compounds responsible for this fact. For example, endophyte-infected seedlings of $L$. perenne were resistant to the weevil Listronotus bonariensis even though the fungus was dead, proving that alkaloids remain bioactive long after the demise of the fungus (Stewart, 1985). Nonetheless, this bioactivity could be broken if alkaloids are target of oxidative processes associated with aging and deteriorating conditions (Walters, 1998). We suggest that a lower antioxidant capacity is

\section{REFERENCES}

Barker, D. J., Davies, E., Lane, G. A., Latch, G. C. M., Nott, H. M., and Tapper, B. A. (1993). "Effect of water deficit on alkaloid concentrations in perennial ryegrass endophyte associations," in Proceedings of the 2nd International Symposium on Acremonium/Grass Interactions, eds D. E. Hume, G. C. M. Latch, and H. S. Easton (Palmerston North), 67-71.

Bastías, D. A., Ueno, A. C., Machado-Assefh, C. R., Alvarez, A. E., Young, C. A., and Gundel, P. E. (2017). Metabolism or behavior: explaining the performance of aphids on alkaloid-producing fungal endophytes in annual ryegrass (Lolium multiflorum). Oecologia 185, 245-256. doi: 10.1007/s00442-0173940-2

Bony, S., and Delatour, P. (2001). "Relevance and impact of grass endophyte toxins in Europe," in The Grassland Conference, eds V. H. Paul and P. D. Dapprich (Soest).

Bush, L. P., Wilkinson, H. H., and Schardl, C. L. (1997). Bioprotective alkaloids of grass-fungal endophyte symbioses. Plant Physiol. 114, 1-7. doi: $10.1104 /$ pp.114.1.1

Clay, K., and Schardl, C. P. (2002). Evolutionary origins and ecological consequences of endophyte symbiosis with grasses. Am. Nat. 160, 99-127. doi: $10.1086 / 342161$

Czarnoleski, M., Olejniczak, P., Mikołajczak, P., Lembicz, M., and Kozłowski, J. (2010). Fungal endophytes protect grass seedlings against herbivory and allow economical seed production. Evol. Ecol. Res. 12, 1-9.

Dirihan, S., Helander, M., Väre, H., Gundel, P. E., Garibaldi, L. A., Irisarri, J. G. N., et al. (2016). Geographic variation in Festuca rubra L. ploidy levels and systemic fungal endophyte frequencies. PLoS ONE 11:e0166264. doi: 10.1371/journal.pone.0166264

Dymock, J. J., Latch, G. C. M., and Tapper, B. A. (1989). "Novel combinations of endophytes in ryegrasses and fescues and their effects on Argentine stem weevil (Listronotus bonariensis) feeding," in Proc Of 5th Australasian Conf. Grassland Invertebrate Ecology, ed P. P. Stahle Melbourne, VIC 28-34.

Faeth, S. H., Bush, L. P., and Sullivan, T. J. (2002). Peramine alkaloid variation in Neotyphodium-infected Arizona Fescue: effects of endophyte and host genotype and environment. J. Chem. Ecol. 28, 1511-1525. doi: 10.1023/A:10199162 27153 associated with a lower concentration of alkaloids. As seed quality parameters decline, the potential for the endophytes to protect the seeds is likely to diminish.

\section{AUTHOR CONTRIBUTIONS}

PG, MAM-G, and CMG designed the research. PG, FB and MAM-M analyzed the data and made the figures. BRVdA, IZ, LPB, and CS performed the analyses for alkaloid and antioxidant quantification. PG, CS, BRVdA, and MAM-M wrote the manuscript. PG edited and submitted the manuscript. All authors have approved the final version of the manuscript.

\section{FUNDING}

This article was supported by the projects PII20150126 (Fondecyt-Chile) and AGL2016-76035-C21R (Spanish, MICINN).

\section{ACKNOWLEDGMENTS}

Authors thank Andrea C. Ueno for his technical assistance of preparing seeds for their analyses.

Falk, J., and Munné-Bosch, S. (2010). Tocochromanol functions in plants: antioxidation and beyond. J. Exp. Bot. 61, 1549-1566. doi: 10.1093/jxb/erq030

Fox, J., and Weisberg, S. (2011). An $\{R\}$ Companion to Applied Regression, 2nd Edn. Thousand Oaks, CA: Sage. Available online at: http://socserv.socsci.mcmaster. $\mathrm{ca} / \mathrm{jfox} /$ Books/Companion

Fuchs, B., Krischke, M., Mueller, M. J., and Krauss, J. (2017a). Herbivore-specific induction of defence metabolites in a grass-endophyte association. Funct. Ecol. 31, 318-324. doi: 10.1111/1365-2435.12755

Fuchs, B., Krischke, M., Mueller, M. J., and Krauss, J. (2017b). Plant age and seasonal timing determine endophyte growth and alkaloid biosynthesis. Fungal Ecol. 29, 52-58. doi: 10.1016/j.funeco.2017.06.003

Gundel, P. E., Garibaldi, L. A., Tognetti, P. M., Aragón, R., Ghersa, C. M., and Omacini, M. (2009). Imperfect vertical transmission of the endophyte Neotyphodium in exotic grasses in grasslands of the Flooding Pampa. Microb. Ecol. 57, 740-748. doi: 10.1007/s00248-008-9447-y

Gundel, P. E., Hamilton, C. E., Seal, C. E., Helander, M., Martínez-Ghersa, M. A., Ghersa, C. M., et al. (2012). Antioxidants in Festuca rubra L. seeds affected by the fungal symbiont Epichloë festucae. Symbiosis 58, 73-80. doi: 10.1007/s13199-012-0194-y

Gundel, P. E., Maseda, P. H., Vila-Aiub, M. M., Ghersa, C. M., and BenechArnold, R. L. (2006). Neotyphodium fungi effects on Lolium multiflorum seed germination in relation to water availability. Ann. Bot. Lond. 97, 571-577. doi: $10.1093 / \mathrm{aob} / \mathrm{mcl} 004$

Gundel, P. E., Pérez, L. I., Helander, M., and Saikkonen, K. (2013). Symbiotically modified organisms: nontoxic fungal endophytes in grasses. Trends Plant Sci. 18, 420-427. doi: 10.1016/j.tplants.2013.03.003

Gundel, P. E., Rudgers, J. A., and Ghersa, C. M. (2011a). Incorporating the process of vertical transmission into understanding of host-symbiont dynamics. Oikos 120, 1121-1128.

Gundel, P. E., Rudgers, J. A., and Whitney, K. D. (2017). Vertically transmitted symbionts as mechanisms of transgenerational effects. Am. J. Bot. 104, 787-792. doi: 10.3732/ajb.1700036

Gundel, P. E., Sorzoli, N., Ueno, A. C., Ghersa, C. M., Seal, C. E., Bastías, D. A., et al. (2015). Impact of ozone on the viability and antioxidant content of grass seeds is affected by a vertically transmitted symbiotic fungus. Environ. Exp. Bot. 113, 40-46. doi: 10.1016/j.envexpbot.2015.01.001 
Gundel, P. E., Zabalgogeazcoa, I., and Vázquez-de-Aldana, B. R. (2011b). Interaction between plant genotype and the symbiosis with Epichloe fungal endophytes in seeds of red fescue (Festuca rubra). Crop Pasture Sci. 62, 1010-1016. doi: 10.1071/CP11300

Hamilton, C. E., and Bauerle, T. L. (2012). A new currency for mutualism: Neotyphodium antioxidants and host drought response. Fungal Divers. 54, 39-49. doi: 10.1007/s13225-012-0156-y

Hamilton, C. E., Gundel, P. E., Helander, M., and Saikkonen, K. (2012). Endophytic mediation of reactive oxygen species and antioxidant activity in plants: a review. Fungal Divers. 54, 1-10. doi: 10.1007/s13225-012-0158-9

Helander, M., Phillips, T., Faeth, S. H., Bush, L. P., and McCulley, R. (2016), Alkaloid quantities in endophy te-infected tall fescue are affected by the plant-fungus combination and environment. J. Chem. Ecol. 42, 118-126. doi: 10.1007/s10886-016-0667-1

Hill, N. S., Rottinghaus, G. E., Agee, C. S., and Schultz, L. M. (1993). Simplified sample preparation for HPLC analysis of ergovaline in tall fescue. Crop Sci. 33, 331-333. doi: 10.2135/cropsci1993.0011183X003300020024x

Huang, W.-Y., Cai, Y.-Z., Xing, J., Corke, H., and Sun, M. (2007). A potential antioxidant resource: endophytic fungi from medicinal Plants. Econ. Bot. 61, 14-30. doi: 10.1663/0013-0001(2007)61[14:APAREF]2.0.CO;2

Jackson, J. A. Jr., Hemken, R. W., Boling, J. A., Harmon, R. J., Buckner, R. C., et al. (1984). Loline alkaloids in tall fescue hay and seed and their relationship to summer fescue toxicosis in cattle. J. Dairy Sci. 67, 104-109. doi: $10.3168 /$ jds.S0022-0302(84)81272-2

Jensen, A. M. D., Mikkelsen, L., and Roulund, N. (2007). Variation in genetic markers and ergovaline production in endophyte (Neotyphodium)-infected fescue species collected in Italy, Spain, and Denmark. Crop Sci. 47, 139-147. doi: $10.2135 /$ cropsci2005.10.0352

Justus, M., Witte, L., and Hartmann, T. (1997). Levels and tissue distribution of loline alkaloids in endophyte-infected Festuca pratensis. Phytochemistry 44, 51-57. doi: 10.1016/S0031-9422(96)00535-3

Kiers, E. T., and West, S. A. (2015). Evolving new organisms via symbiosis. Science 348, 392-394. doi: 10.1126/science.aaa9605

Kranner, I., Minibayeva, F. V., Beckett, R. P., and Seal, C. E. (2010). What is stress? Concepts, definitions and applications in seed science. New Phytol. 188, 655-673. doi: 10.1111/j.1469-8137.2010.03461.x

Leuchtmann, A., Schmidt, D., and Bush, L. P. (2000). Different levels of protective alkaloids in grasses with stroma-forming and seed-transmitted Epichloë/Neotyphodium endophytes. J. Chem. Ecol. 26, 1025-1036. doi: 10.1023/A:1005489032025

Lewis, G. C., and Clements, R. O. (1986). A survey of ryegrass endophyte (Acremonium loliae) in the U.K. and its apparent ineffectuality on a seedling pest. J. Agric. Sci. 107, 633-638. doi: 10.1017/S002185960006980X

Mace, W. J., Lunn, K. L., Kaur, N., and Lloyd-West, C. M. (2014). Variation in the expression of ergot alkaloids between individual tillers of perennial ryegrass. Front. Chem. 2, 1-6. doi: 10.3389/fchem.2014.00107

Menéndez, A. I., A. M. Romero, A. M. Folcia, and Martínez-Ghersa, M. A. (2009). Getting the interactions right: will higher $\mathrm{O}_{3}$ levels interfere with induced defense to aphid feeding? Basic Appl. Ecol. 10, 255-264. doi: 10.1016/j.baae.2008.03.010

Pinheiro, J., Bates, D., DebRoy, S., Sarkar, D., and and, R., Core Team (2017). nlme: Linear and Nonlinear Mixed Effects Models. R package version 3.1-131. Available online at: https://CRAN.R-project.org/package $=$ nlme

Potter, D. A., Stokes, J. T., Redmond, C. T., Schardl, C. L., and Panaccione, D. G. (2008). Contribution of ergot alkaloids to suppression of a grass-feeding caterpillar assessed with gene knockout endophytes in perennial ryegrass. Entomol. Exp. Appl. 126, 138-147. doi: 10.1111/j.1570-7458.2007.00650.x

Rasmussen, S., Parsons, A. J., Bassett, S., Christensen, M. J., Hume, D. E., Johnson, L. J., et al. (2007). High nitrogen supply and carbohydrate content reduce fungal endophyte and alkaloid concentration in Lolium perenne. New Phytol. 173, 787-797. doi: 10.1111/j.1469-8137.2006.01960.x

R. Core Team (2017). R: A Language and Environment for Statistical Computing. R Foundation for Statistical Computing, Vienna. Available online at: https:// www.R-project.org/

Saikkonen, K., Gundel, P. E., and Helander, M. (2013). Chemical ecology mediated by fungal endophytes in grasses. J. Chem. Ecol. 39, 962-968. doi: 10.1007/s10886-013-0310-3
Schardl, C. L., Grossman, R. B., Nagabhyru, P., Faulkner, J. R., and Mallik, U. P. (2007). Loline alkaloids: currencies of mutualism. Phytochemistry 68, 980-996. doi: 10.1016/j.phytochem.2007.01.010

Schardl, C. L., Young, C. A., Pan, J., Florea, S., Takach, J. E., Panaccione, D. G., et al. (2013). Currencies of mutualisms: sources of alkaloid genes in vertically transmitted Epichloae. Toxins 5, 1064-1088. doi: 10.3390/toxins5061064

Seal, C. E., Zammit, R., Scott, P., Flowers, T. J., and Kranner, I. (2010). Glutathione half-cell reduction potential and a-tocopherol as viability markers during the prolonged storage of Suaeda maritima seeds. Seed Sci. Res. 20, 47-53. doi: $10.1017 /$ S0960258509990250

Stewart, A. V. (1985). Perennial ryegrass seedling resistance to Argentine stem weevil. N. Zeal. J. Agr. Res. 28, 403-407. doi: 10.1080/00288233.1985.104 30445

Sullivan, T. J., Rodstrom, J., Vandop, J., Librizzi, J., Graham, C., Schardl, C. L., et al. (2007). Symbiont-mediated changes in Lolium arundinaceum inducible defenses: Evidence from changes in gene expression and leaf composition expression and leaf composition. New Phytol. 176, 673-679. doi: 10.1111/j.1469-8137.2007.02201.x

TePaske, M. R., Powell, R. G., and Clement, S. L. (1993). Analyses of selected endophyte-infected grasses for the presence of loline-type and ergot-type alkaloids. J. Agr. Food Chem. 41, 2299-2303. doi: 10.1021/jf00036a015

Uchitel, A., Omacini, M., and Chaneton, E. J. (2011). Inherited fungal symbionts enhance establishment of an invasive annual grass across successional habitats. Oecologia 165, 465-475. doi: 10.1007/s00442-010-1740-z

Vázquez-de-Aldana, B. R., García-Ciudad, A., García-Criado, B., Vicente-Tavera, S., and Zabalgogeazcoa, I. (2013). Fungal endophyte (Epichloë festucae) alters the nutrient content of Festuca rubra regardless of water availability. PLoS ONE 8:e84539. doi: 10.1371/journal.pone.0084539

Vázquez-de-Aldana, B. R., Zabalgogeazcoa, I., García-Ciudad, A., and GarcíaCriado, B. (2003). Ergovaline occurrence in grasses infected by fungal endophytes of semi-arid pastures in Spain. J. Sci. Food Agric. 83, 347-353. doi: $10.1002 /$ jsfa. 1319

Vázquez-de-Aldana, B. R., Zabalgogeazcoa, I., García-Ciudad, A., and García-Criado, B. (2007). Fungal alkaloids in populations of endophyteinfected Festuca rubra subsp. pruinosa. Grass Forage Sci. 62, 364-371. doi: 10.1111/j.1365-2494.2007.00591.x

Vázquez-de-Aldana, B. R., Zabalgogeazcoa, I., Rubio-de-Casas, R., GarcíaCiudad, A., and García-Criado, B. (2010). Relationships between the genetic distance of Epichloë festucae isolates and the ergovaline and peramine contents of their Festuca rubra hosts. Ann. Appl. Biol. 156, 51-61. doi: $10.1111 / j .1744-7348.2009 .00360 . x$

Walters, C. (1998). Understanding the mechanisms and kinetics of seed aging. Seed Sci. Res. 8, 223-244. doi: 10.1017/S096025850000413X

White, J. F. Jr., and Torres, M. S. (2010). Is plant endophyte-mediated defensive mutualism the result of oxidative stress protection? Physiol. Plantarum 138, 440-446. doi: 10.1111/j.1399-3054.2009.01332.x

Yue, Q., Jonson-Cicalese, J., Gianfagna, T. J., and Meyer, W. A. (2000). Alkaloid production and chinch bug resistance in endophyte-inoculated chewings and strong creeping red fescues. J. Chem. Ecol. 26, 279-292. doi: 10.1023/A:1005410115940

Zabalgogeazcoa, I., García-Ciudad, A., Vázquez-de-Aldana, B. R., and GarcíaCriado, B. (2006). Effects of the infection by the fungal endophyte Epichloë festucae in the growth and nutrient content of Festuca rubra. Eur. J. Agron. 24, 374-384. doi: 10.1016/j.eja.2006.01.003

Conflict of Interest Statement: The authors declare that the research was conducted in the absence of any commercial or financial relationships that could be construed as a potential conflict of interest.

Copyright (C) 2018 Gundel, Seal, Biganzoli, Molina-Montenegro, Vázquez-deAldana, Zabalgogeazcoa, Bush, Martínez-Ghersa and Ghersa. This is an open-access article distributed under the terms of the Creative Commons Attribution License (CC $B Y)$. The use, distribution or reproduction in other forums is permitted, provided the original author(s) and the copyright owner(s) are credited and that the original publication in this journal is cited, in accordance with accepted academic practice. No use, distribution or reproduction is permitted which does not comply with these terms. 